\title{
A longitudinal study of the relation of lead in blood to lead in air concentrations among battery workers
}

\author{
Douglas G Hodgkins, Thomas G Robins, David L Hinkamp, \\ $M$ Anthony Schork, William H Krebs
}

\section{Abstract}

The relation between lead in $\operatorname{air}(\mathbf{P b A})$ and lead in blood $(\mathbf{P b B})$, concentrations was investigated among 44 workers in five major operations in a United States high volume, lead acid battery plant. The study covered a 30 month period in which workers received frequent $\mathrm{PbA}$ and $\mathrm{PbB}$ determinations, workers remained in a single job, and $\mathrm{PbA}$ concentrations averaged below the US Occupational Safety and Health Administration (OSHA) permissible exposure limit of $50 \mu \mathrm{g} / \mathrm{m}^{3}$. In both univariate and multivariable linear regressions, longitudinal analyses averaging $\mathbf{P b A}$ concentrations over the 30 month study period appeared superior to cross sectional analyses using only six month $\mathrm{PbA}$ averages to model $\mathrm{PbB}$ concentrations. The covariate adjusted coefficient ( $\alpha$ value) for $P b A\left(\mu / \mathrm{m}^{3}\right)$ in models of $\mathrm{PbB}(\mu \mathrm{g} / 100 \mathrm{~g})$ was $1 \cdot 14$. This figure is strikingly higher than that reported in previous studies in the lead acid battery industry in all of which PbA concentrations were substantially higher than in the current study. Plausible explanations for the differences in $\alpha$ values include non-linearity of the $\mathrm{PbA-PbB}$ curve, a higher fraction of large size particulate associated with higher $\mathrm{PbA}$ concentrations, survivor bias among workers exposed to higher $\mathrm{PbA}$ concentrations, and the cross sectional designs of most previous studies. Despite previously reported problems with the model used by OSHA to predict PbA-PbB relations, the findings of this study are in good agreement with the predictions of that model.

\section{General Motors Corporation}

D G Hodgkins, W H Krebs

University of Michigan, Occupational Health Program, Department of Environmental and Industrial Health, Ann Arbor, Michigan 48109-2029, USA

T G Robins, D L Hinkamp

University of Michigan, Department of Biostatics, Ann Arbor, Michigan 48109-2029

M A Schork
Lead is a human health hazard with a long history of industrial uses. When United States federal regulators set out to reduce lead exposure in the workplace in the mid-1970s, their decisions were based largely upon studies and models of exposure to lead in the battery industry. Since then, new production technologies have resulted in reductions in lead exposure in most major battery manufacturing plants. ${ }^{1}$

The US Occupational Safety and Health Administration (OSHA) choice of a permissible exposure limit for lead of $50 \mu \mathrm{g} / \mathrm{mg}^{3}$ was determined largely by a model which predicted the distribution of workers' blood lead concentrations for a given air lead exposure. $^{2}$ This model was based on experimental data concerning the relation of lead absorption to lead particulate size and on a set of assumptions, without an empirical basis, regarding lead particulate size distributions in the lead battery industry. ${ }^{3}$ We recently showed that this set of assumptions differed in important respects from empirical data received from the lead battery industry. ${ }^{4}$ If the OSHA model were to be directly applied to the actual particle size distributions, significantly lower blood lead concentrations would be predicted for a given air lead exposure. None the less, many previous studies in the lead battery industry of the relation between total air lead $(\mathrm{PbA})$ and blood lead $(\mathrm{PbB})$ concentrations have been in rough agreement with the unmodified OSHA predictions. $^{5-10}$ These studies have usually considered only a limited number of covariates, however, and have not directly examined the relative contributions of various particulate size fractions to lead body burden. Also, most of these studies have been cross sectional in design. Other investigations have suggested that longitudinal study designs may be required to model accurately $\mathrm{PbA}-\mathrm{PbB}$ relations. ${ }^{112}$ Accurate modelling of $\mathrm{PbA}-\mathrm{PbB}$ relations, particularly at air lead concentrations below the current standard is of concern in the light of recent reports of adverse health effects at increasingly lower blood lead concentrations. ${ }^{13}$ These reports place a possible lowering of the current legal limits for worker blood lead concentrations and the associated air lead concentrations on the scientific and policy agenda. 
We present here a study that investigated the relation between $\mathrm{PbA}$ and $\mathrm{PbB}$ concentrations in 44 lead acid battery workers in one United States plant who were followed up for 30 months with frequent $\mathrm{PbA}$ and $\mathrm{PbB}$ determinations. This plant used modern battery manufacturing technology and the $\mathrm{PbA}$ concentrations found were low (usually $\left.<30 \mu \mathrm{g} / \mathrm{m}^{3}\right)$. Several potentially important covariates were considered including job category, seniority, age, ethnicity, sex, and smoking habit.

The 44 participants comprised workers at the plant with less than or equal to 22 years seniority. As described elsewhere, ${ }^{14}$ the 24 workers at the plant with more than 22 years seniority were excluded from further analyses owing to the apparently strong influence of high $\mathrm{PbA}$ exposures in the distant past on current $\mathrm{PbB}$ concentrations.

This paper focuses on differences between cross sectional and longitudinal models of $\mathrm{PbA}-\mathrm{PbB}$ relations and a comparison of the current results with previous observational and experimental studies. The results presented here form part of a larger study, which also examined the effect of inclusion of information on particulate size distributions on $\mathrm{PbA}$ PbB models. ${ }^{14}$

\section{Methods}

The plant is located in an eastern United States urban area and was built in the 1940s. It was converted from older grid moulding production processes to expanded grid processes in 1977-8. The plant continued to use these modern production processes from the time of their installation through the entire study period. Details of the production process have been provided elsewhere. ${ }^{14}$ The plant is an older "bay style" plant, having a high bay low bay roof structure with many windows. Tempered makeup air is provided only in cool weather. Batteries for starting car, truck, and boat engines are produced at the facility. Maximum battery production at the plant was reported to be 12000 to 14000 units per day.

Eight manufacturing operations (job categories) were initially evaluated for possible study because they offered the highest potential for worker lead exposure. (see bold bordered processes in the figure) Of these eight, five job categories were selected for study because four or more workers were assigned to each category and workers in these categories did not wear respirators. These five job categories selected were plate pasting, offbearing, encapsulation, stacking, and cast-on-strap.

\section{Air lead ( $\mathrm{PbA}$ ) and blood lead ( $\mathrm{PbB}$ ) sampling programme}

Historical (1980-8) $\mathrm{PbA}$ and $\mathrm{PbB}$ sampling and analysis in the plant met or exceeded the require- ments of the OSHA lead standard. ${ }^{2}$ A trained technician performed the $\mathrm{PbA}$ sampling on representative workers in each job category for at least seven continuous hours. No formal procedure was adopted for selecting workers to be sampled; however, attempts were made to sample most operator locations within each job category across all work shifts during a calendar year. Air sampling was performed by attaching a $37 \mathrm{~mm}$ cassette containing a $0.8 \mu \mathrm{m}$ nominal pore size, mixed cellulose acetate filter to the lapel of the workers. The air sampling pumps, attached to the workers belts, were connected to the filter cassettes by rubber hose. A flow rate of $2 \mathrm{l} / \mathrm{min}$ was used. Pump calibrations were made using a 11 bubble tube.

Venous blood samples for $\mathrm{PbB}$ measurements were collected by a registered nurse from all workers in the selected job categories on a frequent basis. Two to four samples were typically collected from each worker in any six month period.

A single analytical laboratory was used to analyse the $\mathrm{PbA}$ and $\mathrm{PbB}$ samples from 1980-5. Air sample filters were digested and then analysed by atomic absorption spectrophotometry. Concentrations of $\mathrm{PbB}$ were determined by delves cup techniques on a separate atomic absorption spectrophotometer. This laboratory was accredited by the American Industrial Hygiene Association (AIHA) and participated in the Centres for Disease Control (CDC) blood lead proficiency programme and was a proficiency analytical testing (PAT) programme approved for lead sample analysis. In 1986, a new laboratory was chosen to analyse samples for $\mathrm{PbA}$ and $\mathrm{PbB}$ concentrations.

\section{DATA SELECTION}

Records for $\mathrm{PbA}$ concentrations were reviewed for the years 1980 to the end of the third quarter of 1988 in the selected job categories. In linear regression analyses over the nearly nine year period, the average change in $\mathrm{PbA}$ concentration per year was small (from -0.39 to $0.89 \mu \mathrm{g} / \mathrm{m}^{3}$ per year across the five job categories).$^{14}$ Quarterly mean $\mathrm{PbA}$ concentrations and detailed regression results have been reported elsewhere. ${ }^{414}$ The recessionary period for the car industry in the early 1980 s resulted in many workers being on lay off or changing job categories. As a result, relative job category was stable only after the middle of 1983 .

As a result of the above considerations, the period from the last half of 1983 (designated 1983b) to the end of the last half of 1985 (1985b) was selected for study. This resulted in a 30 month study period during which there were regular samples for the measurement of $\mathrm{PbA}$ and $\mathrm{PbB}$ concentrations collected from the study population, steady exposures, stability of worker job assignments and a single, approved laboratory performing all lead analyses. 


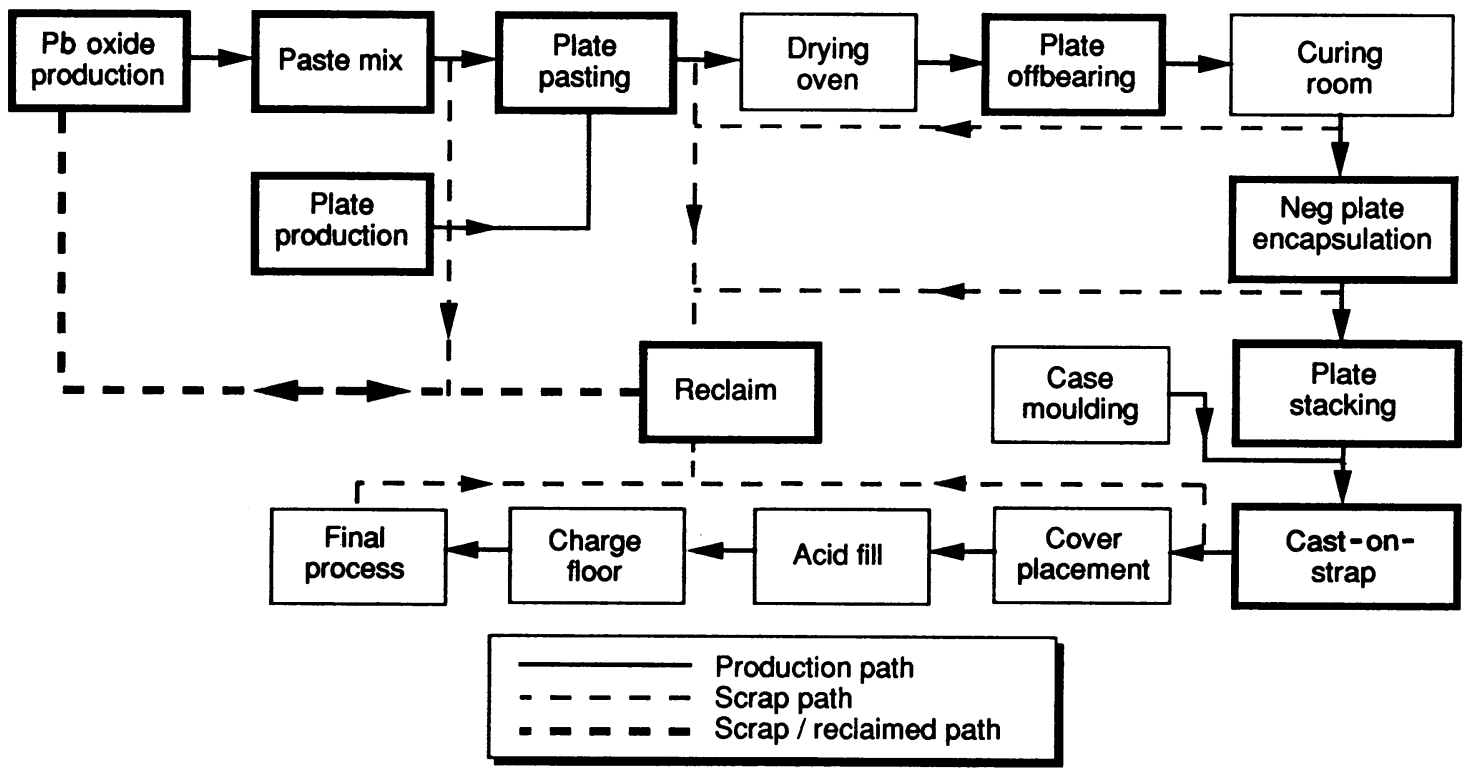

Battery manufacturing operation: expanded metal processes.

Workers' personnel and medical records were reviewed to obtain job assignment, work absence history, sex, ethnicity, cigarette smoking history, plant seniority, and age. Concentrations of $\mathrm{PbA}$ and $\mathrm{PbB}$ were collapsed into six month arithmetic means for the five periods of six months each from 1983b to 1985b. Each worker in the study had a $\mathrm{PbB}$ measurement for at least one sample for each of the six month periods, and most had two to four samples analysed during each period.

\section{STUDY POPULATION}

Workers selected for study were initially identified in a data base that included extensive data on job assignements. The records were updated on a weekly basis for change in work state that included job transfer and sick leave information. Workers missing from their job category for $\mathbf{4 0}$ or more weeks (10 months) during the time period July 1983 to the end of December 1985 were deleted from the analysis. Workers missing more than four weeks in the last six months of the study (second half of 1985) were also deleted.

Preliminary analyses of the worker population meeting this cohort definition showed an apparent effect of past $\mathrm{PbA}$ exposures on the $\mathrm{PbB}$ concentrations of workers with more than 22 years of plant seniority. ${ }^{14} \mathrm{~A}$ significant $\mathrm{PbA}-\mathrm{PbB}$ relation was not present in this subset of workers and appeared to be the result of past $\mathrm{PbA}$ concentrations well in excess of those measured after the change to expand metal grid technologies. This lack of association was also present in a study of another battery plant from the same company. ${ }^{14}$ As a result, this study's analysis of particle size was restricted to the subset of workers with less than or equal to 22 years of plant seniority.

\section{STATISTICAL ANALYSES}

Both univariate and multivariable linear regression models were examined cross sectionally and longitudinally. Cross sectional $\mathrm{PbB}-\mathrm{PbA}$ regression analyses were performed by regressing the mean $\mathrm{PbB}$ concentration for the workers against the mean $\mathrm{PbA}$ concentration for the concurrent six month period. Longitudinal analyses were performed by regressing the mean $\mathrm{PbB}$ concentration for each of the five six month periods (1983b, 1984a, 1984b, 1985a, 1985b) against the arithmetic average of the six month $\mathrm{PbA}$ concentration means up to and including the concurrent six month study period. For example, the mean $\mathrm{PbB}$ concentration in $1984 \mathrm{~b}$ was regressed against the arithmetic average of the $\mathrm{PbA}$ concentrations in 1983b, 1984a, and 1984b. Covariates initially considered for the multivariable analyses included seniority and indicator variables for job, sex, ethnicity, and smoking habit. The final longitudinal model ( $\mathrm{PbB}$ concentration in 1985b against the average $\mathrm{PbA}$ concentration for the entire 30 month study period) was examined for covariates significant at $\mathrm{p}<0 \cdot 15$. Three covariates, paste machine, black race, and smoking habit (coded as a no or yes variable), were retained in the model. The same three 
covariates were included in all the other multivariable models for comparability of results across models.

\section{Results \\ A total of 53 workers with less than or equal to 22 years of seniority worked in designated job categories during the study period. After assessment of work histories, nine of these workers were excluded from the study population because of absences resulting in the final study population of 44 . None of these nine were excluded because of high blood lead measure- ments triggering OSHA required medical removal, but rather because of absence from their job categories as a result of elective transfers or personal sick leave not known to be related to exposure to lead. \\ Of the 44 final study subjects, $84 \%$ were men, $41 \%$ white (non-Hispanic), $9 \%$ Hispanic, $50 \%$ black, and $66 \%$ current smokers. Smokers in these groups were identified by review of questionnaires completed by workers and nurses at the time of periodic, roughly annual, physical examinations. No changes in worker smoking habits during the study period (for example,}

starting or stopping) were found on these questionnaires. The mean age was 41.8 years; mean seniority was 12.8 years; mean total absences during the 30 month study and during the last half of 1985 were 1.4 and 0.05 months respectively. Thirteen worked in cast-on-strap, 14 in encapsulation, eight as offbearers, six on paste machine, and three as stackers. Mean blood lead concentrations for the last half of 1985 was $29.1 \mu \mathrm{g} / 100 \mathrm{~g}$ with a range of job specific means from $23.0 \mu \mathrm{g} / 100 \mathrm{~g}$ for encapsulation to $39.7 \mu \mathrm{g} / 100 \mathrm{~g}$ for paste machine.

Table 1 presents the job specific $\mathrm{PbA}$ and $\mathrm{PbB}$ concentrations for each of the five half year periods. A total of 219 air samples was collected over the 30 month period. Half year mean $\mathrm{PbA}$ concentrations varied from a low of $5 \mu \mathrm{g} / \mathrm{m}^{3}$ (stacker in 1985b) to a high of $33 \mu \mathrm{g} / \mathrm{m}^{3}$ (cast on strap in 1985a). The two and a half year job category means ranged from 11 to $19 \mu \mathrm{g} / \mathrm{m}^{3}$. Half year mean $\mathrm{PbB}$ concentrations varied from a low of $21 \mu \mathrm{g} / 100 \mathrm{~g}$ (stacker in 1985a) to a high of $40 \mu \mathrm{g} / 100 \mathrm{~g}$ (paste machine in 1985a). There were no statistically significant trends over time for either $\mathrm{PbA}$ or $\mathrm{PbB}$ in any of the five job categories.

Table 2 shows the results of the cross sectional and

Table 1 Worker $\mathrm{PbA}$ concentrations in $\mu \mathrm{g} / \mathrm{m}^{3}$ and $\mathrm{PbB}$ concentrations in $\mu \mathrm{g} / 100 \mathrm{~g}$, by job category

\begin{tabular}{|c|c|c|c|c|c|c|c|c|c|c|c|c|c|c|c|c|c|}
\hline \multirow[b]{2}{*}{ Job category } & \multicolumn{10}{|c|}{$P b A$ half year means (SD) } & \multirow{2}{*}{$\begin{array}{l}P b A \\
\text { mean } \dagger\end{array}$} & \multicolumn{6}{|c|}{$P b B$ half year means (SD) } \\
\hline & $83 b$ & $N^{\star}$ & $84 a$ & $\mathrm{No}^{\prime}$ & $84 b$ & $N o^{\star}$ & $85 a$ & No & $85 b$ & $N o^{\star}$ & & Nof & $83 b$ & $84 a$ & $84 b$ & $85 a$ & $85 b$ \\
\hline $\begin{array}{l}\text { Cast-on-strap } \\
\text { Encapsulation } \\
\text { Paste machine } \\
\text { Offbearer } \\
\text { Stacker }\end{array}$ & $\begin{array}{r}12(7 \cdot 7) \\
10(6 \cdot 3) \\
10(5 \cdot 2) \\
17(9 \cdot 7) \\
9(4 \cdot 4)\end{array}$ & $\begin{array}{r}15 \\
16 \\
8 \\
10 \\
8\end{array}$ & $\begin{array}{l}14(17) \\
15(8 \cdot 2) \\
26(17) \\
13(5 \cdot 3) \\
23\end{array}$ & $\begin{array}{r}5 \\
12 \\
7 \\
8 \\
1\end{array}$ & $\begin{array}{r}15(9 \cdot 2) \\
13(8 \cdot 0) \\
16(7 \cdot 3) \\
14(6 \cdot 6) \\
8(4 \cdot 5)\end{array}$ & $\begin{array}{r}9 \\
13 \\
5 \\
10 \\
17\end{array}$ & $\begin{array}{l}33(22) \\
10(5 \cdot 0) \\
20(13) \\
8(3 \cdot 0) \\
10(2 \cdot 6)\end{array}$ & $\begin{array}{l}9 \\
8 \\
9 \\
3 \\
5\end{array}$ & $\begin{array}{c}19(15) \\
6(0.9) \\
15(12) \\
16 \\
5(2 \cdot 8)\end{array}$ & $\begin{array}{r}25 \\
6 \\
3 \\
1 \\
6\end{array}$ & $\begin{array}{l}19 \\
11 \\
17 \\
14 \\
11\end{array}$ & $\begin{array}{r}13 \\
14 \\
6 \\
8 \\
3\end{array}$ & $\begin{array}{l}27(8 \cdot 5) \\
24(5 \cdot 5) \\
31(6 \cdot 9) \\
25(7 \cdot 2) \\
23(7 \cdot 2)\end{array}$ & $\begin{array}{l}27(7 \cdot 4) \\
22(4 \cdot 2) \\
33(5 \cdot 0) \\
23(6 \cdot 3) \\
21(6 \cdot 7)\end{array}$ & $\begin{array}{l}31(9 \cdot 0) \\
24(6 \cdot 0) \\
36(6 \cdot 0) \\
25(8 \cdot 1) \\
18(7 \cdot 2)\end{array}$ & $\begin{array}{l}30(8 \cdot 4) \\
22(5 \cdot 0) \\
37(7 \cdot 9) \\
27(7 \cdot 9) \\
21(4 \cdot 0)\end{array}$ & $\begin{array}{l}33(8.9) \\
23(3.9) \\
40(6.7) \\
28(6.6) \\
24(6.5)\end{array}$ \\
\hline
\end{tabular}

*Total number of personal breathing zone samples taken for each job category in each half year.

† Mean of five half year means.

$\ddagger$ Number of study subjects undergoing $\mathrm{PbB}$ sampling in each half year (all subjects provided samples in each half year).

Table 2 Cross sectional and longitudinal regression models of relations of $\mathrm{PbA}\left(\mu \mathrm{g} / \mathrm{m}^{3}\right)$ to $\mathrm{PbB}(\mu \mathrm{g} / 100 \mathrm{~g})$ among 44 battery workers

\begin{tabular}{|c|c|c|c|c|c|c|c|c|c|c|c|c|}
\hline \multicolumn{4}{|c|}{ Univariate models } & \multicolumn{9}{|c|}{ Multivariable models } \\
\hline \multirow[b]{2}{*}{ Year } & \multicolumn{2}{|l|}{$P b A$} & \multirow[b]{2}{*}{ Model $r^{2}$} & \multicolumn{2}{|l|}{$P b A$} & \multicolumn{2}{|c|}{ Current smoker } & \multicolumn{2}{|c|}{ Paste machine } & \multicolumn{2}{|c|}{ Black race } & \multirow[b]{2}{*}{ Model $r^{2}$} \\
\hline & Coeff & p Value & & Coeff & p Value & Coeff & p Value & Coeff & p Value & Coeff & p Value & \\
\hline \multicolumn{13}{|c|}{ Cross sectional ${ }^{\star}$} \\
\hline $\begin{array}{l}1983 b \\
1984 a \\
1984 b \\
1985 a \\
1985 b\end{array}$ & $\begin{array}{r}-0.01 \\
0.51 \\
2.35 \\
0.28 \\
0.75\end{array}$ & $\begin{array}{l}0.98 \\
0.03 \\
0.0003 \\
0.02 \\
0.0005\end{array}$ & $\begin{array}{l}0.00 \\
0.11 \\
0.27 \\
0.13 \\
0.26\end{array}$ & $\begin{array}{r}0.10 \\
-0.37 \\
1.80 \\
0.24 \\
0.59\end{array}$ & $\begin{array}{l}0.81 \\
0.33 \\
0.006 \\
0.02 \\
0.0009\end{array}$ & $\begin{array}{l}\mathbf{5 . 4 6} \\
\mathbf{5} \cdot 73 \\
\mathbf{6} \cdot 96 \\
\mathbf{5} \cdot 93 \\
\mathbf{5 . 8 9}\end{array}$ & $\begin{array}{l}0.02 \\
0.005 \\
0.004 \\
0.01 \\
0.007\end{array}$ & $\begin{array}{r}4.04 \\
11 \cdot 23 \\
3 \cdot 06 \\
8 \cdot 56 \\
8.46\end{array}$ & $\begin{array}{l}0.21 \\
0.03 \\
0.38 \\
0.008 \\
0.005\end{array}$ & $\begin{array}{l}1.42 \\
0.34 \\
0.94 \\
1.83 \\
2.00\end{array}$ & $\begin{array}{l}0.69 \\
0.85 \\
0.65 \\
0.38 \\
0.29\end{array}$ & $\begin{array}{l}0.22 \\
0.38 \\
0.44 \\
0.44 \\
0.55\end{array}$ \\
\hline \multicolumn{13}{|c|}{ Longitudinal $\uparrow$} \\
\hline $\begin{array}{l}1983 b \\
1984 a \\
1984 b \\
1985 a \\
1985 b\end{array}$ & $\begin{array}{r}-0.01 \\
1.22 \\
2.42 \\
1.43 \\
1.50\end{array}$ & $\begin{array}{l}0.98 \\
0.03 \\
0.005 \\
0.0004 \\
0.0001\end{array}$ & $\begin{array}{l}0.00 \\
0.11 \\
0.18 \\
0.26 \\
0.36\end{array}$ & $\begin{array}{l}0.10 \\
0.64 \\
0.86 \\
0.97 \\
1.14\end{array}$ & $\begin{array}{l}0.81 \\
0.42 \\
0.61 \\
0.01 \\
0.0003\end{array}$ & $\begin{array}{l}5 \cdot 46 \\
5 \cdot 83 \\
7 \cdot 11 \\
5 \cdot 80 \\
5 \cdot 72\end{array}$ & $\begin{array}{l}0.02 \\
0.005 \\
0.007 \\
0.01 \\
0.007\end{array}$ & $\begin{array}{l}4 \cdot 04 \\
9 \cdot 97 \\
4 \cdot 18 \\
5 \cdot 79 \\
6 \cdot 22\end{array}$ & $\begin{array}{l}0.21 \\
0.03 \\
0.57 \\
0.08 \\
0.03\end{array}$ & $\begin{array}{l}1.42 \\
0.70 \\
1.01 \\
1.72 \\
2.70\end{array}$ & $\begin{array}{l}0.69 \\
0.69 \\
0.66 \\
0.40 \\
0.14\end{array}$ & $\begin{array}{l}0.22 \\
0.37 \\
0.33 \\
0.45 \\
0.57\end{array}$ \\
\hline
\end{tabular}

*Cross sectional models regress mean $\mathrm{PbB}$ concentration in each six month period against mean $\mathrm{PbA}$ concentration in the same period.

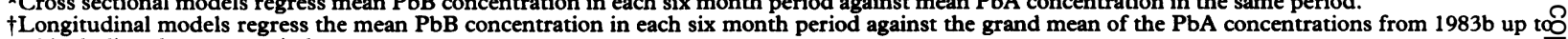
and including the same period. 
longitudinal analyses. Each line in this table represents the outcomes of two separate regression models, one univariate and one multivariable. For the univariate analyses, the last four cross sectional models showed a statistically significant $\mathrm{PbA}-\mathrm{PbB}$ association. However, the estimate of the coefficient appeared unstable and ranged from 0.51 in 1984a to 2.35 in 1984b. The last four longitudinal models also showed statistically significant $\mathrm{PbA}-\mathrm{PbB}$ associations. In this case the coefficients appeared to converge to the final value of $1 \cdot 50$. Moreover, the $p$ value decreased and the $r^{2}$ increased in each subsequent model. The $r^{2}$ of 0.36 in the final model compared favourably with the $r^{2}$ values in any of the cross sectional univariate models. In multivariable analyses, the last three cross sectional models showed a statistically significant $\mathrm{PbA}-\mathrm{PbB}$ association. Again, the estimate of the $\mathrm{PbA}$ coefficient appeared unstable and ranged from 0.24 to 1.80 . Only in the last two longitudinal analyses were there statistically significant $\mathrm{PbA}-\mathrm{PbB}$ associations with similar values for the $\mathrm{PbA}$ coefficient of 0.97 and 1.14 respectively. In all the multivariable models, being a current smoker was significantly positively associated with $\mathrm{PbB}$. In most, work on the paste machine was also significantly, positively associated with $\mathrm{PbB}$ concentrations. Black race was of borderline significance only in the final longitudinal model. This model also evidenced the lowest $p$ value for the $\mathrm{PbA}$ coefficient $(0.0003)$ and the highest overall $r^{2}(0.57)$ of any of the multivariable models.

In interpreting the findings presented in table 2 , it is important to note that 20 of the 44 workers studied were recalled to their jobs during the second half of 1983 after nine to 10 month layoffs. Most of the remaining workers would have changed jobs during this same period owing to seniority prerogatives. Thus, the initial poor $\mathrm{PbA}-\mathrm{PbB}$ correlation in $1983 \mathrm{~b}$ with subsequent improvement as seen in table 2 would not be unexpected.

Table 3 Summary of battery plant studies

\begin{tabular}{|c|c|c|c|c|c|c|}
\hline Study & $\begin{array}{l}\text { Year } \\
\text { reported }\end{array}$ & $\begin{array}{l}\text { No of } \\
\text { workers }\end{array}$ & Study type & $\begin{array}{l}P b A^{\star} \text { range } \\
\left(m c g / m^{3}\right)\end{array}$ & $\alpha \dagger$ & Comments \\
\hline Williams et $a l^{6}$ & 1969 & 39 & Cross sectional & $<5-300$ & $0 \cdot 20$ & $\begin{array}{l}\text { Ten day study, mean of } 10 \mathrm{PbA} \\
\text { samples regressed against mean of } \\
\text { duplicate PbB samples taken on one } \\
\text { day-old process technology }\end{array}$ \\
\hline King $e t a l^{8}$ & 1979 & 19 & Cross sectional & $100-800$ & 0.03 & $\begin{array}{l}\text { Three month study, mean of } 10 \mathrm{PbA} \\
\text { samples regressed against mean of } \\
\text { three } \mathrm{PbB} \text { samples collected at } \\
\text { beginning, middle, and end of study- } \\
\text { old process technology. }\end{array}$ \\
\hline Gartside $e t a l^{7}$ & 1982 & 132 & Cross sectional & $<10-350$ & 0.54 & $\begin{array}{l}\text { Study performed during one year } \\
\text { period; however, individual } \mathrm{PbB} \text { result } \\
\text { was regressed against a } \mathrm{PbA} \text { result } \\
\text { within } 30 \text { days of } \mathrm{PbB} \text { sample—old } \\
\text { process technology. }\end{array}$ \\
\hline Bishop and $\mathrm{Hill}^{9}$ & 1983 & 233 & Cross sectional & $<10-200$ & 0.04 & $\begin{array}{l}\text { Study performed over one year period, } \\
\text { year mean } \mathrm{PbB} \text { concentration was } \\
\text { regressed against year mean } \mathrm{PbA} \\
\text { level-no information on operations- } \\
\text { old process technology? }\end{array}$ \\
\hline Bishop and $\mathrm{Hill}^{9}$ & 1983 & ? & Longitudinal & ? & ? & $\begin{array}{l}\text { Study performed over about five and a } \\
\text { half years, weighted monthly plant } \\
\mathrm{PbA} \text { concentrations were used in a } \\
\text { time series analysis with monthly plant } \\
\mathrm{PbB} \text { concentrations, four of six plants } \\
\text { from cross sectional study used-no } \\
\text { information provided on operations or } \\
\text { number of workers included-old } \\
\text { process technology? }\end{array}$ \\
\hline Chavalitnitikul et $a l^{10}$ & 1984 & 19 & Cross sectional & $2-165$ & $0 \cdot 16$ & $\begin{array}{l}\text { Ten day study, mean of } 10 \mathrm{PbA} \\
\text { samples regressed against a single PbB } \\
\text { sample collected during study-mostly } \\
\text { old processes, possible newer } \\
\text { encapsulation process as a single } \\
\text { worker classified as "plate wrapper." }\end{array}$ \\
\hline Matte et $a l^{5}$ & 1989 & 32 & Cross sectional & $30-5300$ & 0.05 & $\begin{array}{l}\text { Single } \mathrm{PbA} \text { measure regressed against } \\
\text { single } \mathrm{PbB} \text { measure—old process } \\
\text { technology. }\end{array}$ \\
\hline Current Study & 1991 & 44 & Longitudinal & $5-33$ & $1 \cdot 14$ & $\begin{array}{l}\text { Mean } \mathrm{PbA} \text { concentration over three } \\
\text { year period regressed against mean } \\
\mathrm{PbB} \text { concentrations during last half } \\
\text { year of three year period-new process } \\
\text { technology. }\end{array}$ \\
\hline
\end{tabular}




\section{Discussion}

This study differs in several respects from most prior studies examining $\mathrm{PbA}-\mathrm{PbB}$ relations. Firstly, it is a longitudinal design - that is, $\mathrm{PbA}$ concentrations averaged over a long period ( 30 months) were used to model $\mathrm{PbB}$ concentrations during the final six months of that three year period. Secondly, several potentially important covariates (smoking, specific job, ethnicity, and seniority) were controlled for in analyses. Thirdly, $\mathrm{PbA}$ concentrations were substantially lower than in most comparable studies in the lead acid battery industry. This is probably due to the fact that most of these previous studies are based on data collected before the promulgation of the OSHA lead standard and to the introduction of newer manufacturing technologies.

Table 3 summarises the design and findings of this and the major previous studies in the lead acid battery industry. All of the previous studies, except one by Bishop and Hill, ${ }^{9}$ were cross sectional in design and examined workers using older manufacturing technologies (for example, grid moulding, manual or semiautomatic plate pasting, manual "plate dressing," and the use of individual plate separators). The "longitudinal" Bishop and Hill study did not provide information on which occupations were included, worker movements between jobs, or the air sampling scheme. In each of the previous studies for which information is available, the upper ranges of $\mathrm{PbA}$ exposures were substantially higher than in the current study. For each previous study, the value of the coefficient for $\mathrm{PbA}$ in a linear regression model of $\mathrm{PbB}$, commonly known as $\alpha$, is shown. The range of values of $\alpha$ for these studies $(0.03$ to 0.54$)$ is strikingly lower than the covariate adjusted estimate of $1 \cdot 14$ or the unadjusted value of 1.50 for the current study.

There are at least four plausible explanations for the higher value of $\alpha$ found in the current study. Firstly, probable non-linearity of the $\mathrm{PbA}-\mathrm{PbB}$ curve (the apparently decreasing values of $\alpha$ at higher $\mathrm{PbA}$ concentrations). This non-linearity has been reported in several previous studies ${ }^{15-17}$ including experimental studies in which particulate size was controlled, ${ }^{1516}$ and has been discussed extensively in review articles by Hammond et $a l^{18}$ and by Chamberlain. ${ }^{19}$ Secondly, higher workplace $\mathrm{PbA}$ concentrations may generally be associated with a greater fraction of the total particulate being composed of larger particles, which would be expected to deposit predominantly in the ciliated airways and naso and oropharynx and ultimately to be ingested. Lead which is ingested is absorbed from the gastrointestinal tract with roughly $8 \%$ efficiency as compared with nearly $100 \%$ efficiency for lead depositing deep in the lung. ${ }^{1520-22}$ An association of higher $\mathrm{PbA}$ concentrations with larger particle sizes was assumed in the model used in the OSHA
Table 4 a Values (ratio $\mathrm{PbB} / \mathrm{PbA}$ ) of several experimental and environmental studies (from Chamberlain ${ }^{19}$ )

\begin{tabular}{|c|c|c|c|}
\hline Study & $\alpha^{\star}($ mean $)$ & $\begin{array}{l}P b A \\
\left(\mu g / m^{3}\right)\end{array}$ & Study type \\
\hline $\begin{array}{l}\text { Kehoe }^{15} \\
\text { Griffin } \text { et al } \\
\text { Azar et } a l^{17} \\
\text { Tepper and Levin }{ }^{24} \\
\text { Tsuchiya } \\
\text { Johnson } \\
\text { Current study }\end{array}$ & $\begin{array}{l}0.83 \\
0.65 \\
1.45 \\
1.8 \\
1 \cdot 81 \\
1.09 \\
3.09 \\
1 \cdot 11 \\
4 \cdot 79 \dagger\end{array}$ & $\begin{array}{l}3 \cdot 99 \pm 2 \cdot 40 \\
24 \cdot 0 \pm 9 \cdot 02 \\
10 \cdot 4 \\
3 \cdot 1 \\
0 \cdot 1-6 \cdot 1 \\
0 \cdot 2-3 \cdot 4 \\
0 \cdot 2-1 \cdot 3 \\
0 \cdot 6-6 \cdot 3 \\
5-33\end{array}$ & $\begin{array}{l}\text { Experimental } \\
\text { Experimental } \\
\text { Experimental } \\
\text { Experimental } \\
\text { Environmental } \\
\text { Environmental } \\
\text { Environmental } \\
\text { Environmental } \\
\text { Occupational }\end{array}$ \\
\hline
\end{tabular}

${ }^{\star} \alpha$ Values determined by either point estimates or regression analysis exposures represent a 24 hour/7 day week equivalent. $\dagger \alpha$ Value based on 40 hour work week adjusted to 24 hour $/ 7$ days per week equivalent $(4.79=1.14 \times 168 / 40)$.

standard to predict $\mathrm{PbA}-\mathrm{PbB}$ relations. ${ }^{3}$ Also, particulate size data previously reported from the current investigation found this type of distribution pattern. ${ }^{4}$

Thirdly, in the previous cross sectional studies that have $\mathrm{PbA}$ concentrations ranging well above the current OSHA standard of $50 \mu \mathrm{g} / \mathrm{m}^{3}$, a form of survivor bias may be reducing the apparent value of $\alpha$. Those workers with high individual values of $\alpha$ would be the most likely to develop clinically apparent lead toxicity (or simply, pronounced increases in $\mathrm{PbB}$ concentrations) and be removed from the exposure on this basis reducing the mean $\alpha$ value among the remaining workers. Such an effect is unlikely to be operative to a significant degree at $\mathrm{PbA}$ concentrations below $50 \mu \mathrm{g} / \mathrm{m}^{3}$ as found in the current study.

Fourthly, most of the previous studies modelled $\mathrm{PbB}$ concentrations based on either concurrent $\mathrm{PbA}$ concentrations or on those collected during only a brief period before measurement of $\mathrm{PbB}$ concentrations. The data from the current study (table 2) and many earlier studies of lead elimination kinetics ${ }^{10-1223}$ suggest that incorporation of $\mathrm{PbA}$ exposures for several years before $\mathrm{PbB}$ measurement will improve predictions. Thus the failure of these previous studies to include longitudinal $\mathrm{PbA}$ data can be viewed as a form of non-differential misclassification of exposure tending to result in bias towards the null-that is, to decreased values of $\alpha$. Also, most of these earlier studies have not included potentially important covariates in their models. Based on our current data, smoking habit and indicator variables for specific jobs appear particularly important. Data presented elsewhere ${ }^{4}$ suggest that paste machine was a significant covariate because of the relatively higher proportion of small size particulate on this job as compared with the other jobs. Of course, inclusion of covariates could adjust the $\alpha$ value either upward or downward. In our data, their inclusion resulted in a reduction in $\alpha$. 
A comparison of the $\alpha$ value obtained in the current study with those obtained in experimental and environmental studies in which $\mathrm{PbA}$ concentrations were similar or lower than in the current study is informative. As seen in table 4 (adapted from Chamberlain ${ }^{19}$ ), the $\alpha$ value in the current study still appears higher than expected although it is somewhat closer to the range found in these studies as compared with the occupational studies shown in table 3 . It should be noted that the validity of the $168 / 40$ correction factor described in the footnote in table 4 is dependent on the assumption that the respiratory volume inhaled per unit time is the same during working and non-working periods. A higher respiratory rate during work periods may explain some part of the higher $\alpha$ value in the current study.

Finally, of interest is a comparison of the $\alpha$ for the current study with the $\alpha$ for the low exposed groups in the study by Williams et al included in table 3 . The study ${ }^{6}$ included two groups of workers from plastics departments as the "non-exposed" groups. In fact, the mean $\mathrm{PbA}$ exposures of 12 and $9 \mu \mathrm{g} / \mathrm{m}^{3}$ in plastics department $A$ and $B$ respectively are similar to the $\mathrm{PbA}$ exposures in the current study (table 1). Moreover, the $\alpha$ values of 0.93 and 1.46 found for workers in departments A and B respectively are remarkably similar to those of the current study.

If, in fact, the current study can be considered to be of a stronger design than most previous occupational studies, it is important to consider what the policy implications of our results may be. As we have described previously, ${ }^{4}$ there appear to be several potential problems with the model chosen by OSHA to predict $\mathrm{PbB}$ concentrations based on $\mathrm{PbA}$ concentrations. Primary among these is that the assumptions of the model regarding particulate size distributions were not borne out by an empirical study of the lead acid battery industry. In a seniority range of three to 20 years, the OSHA model predicts $\mathrm{PbB}$ concentrations of approximately $28-32 \mu \mathrm{g} / 100 \mathrm{~g}$ for a $\mathrm{PbA}$ exposure of $11 \mu \mathrm{g} / \mathrm{m}^{3}$ and approximately $30-35 \mu \mathrm{g} / 100 \mathrm{~g}$ for a $\mathrm{PbA}$ exposure of $19 \mu \mathrm{g} / \mathrm{m}^{2}$. Despite the potential concerns with the OSHA model, our results are in good agreement with the model predictions.

In summary, the current study is notable, firstly, for showing differences in the modelled $\mathrm{PbA}-\mathrm{PbB}$ relations when cross sectional analyses are compared with longitudinal analyses based on three years of $\mathrm{PbA}$ measures (table 2). The greater stability of the longitudinal analyses suggests that, at least in situations such as the current study where individual $\mathrm{PbA}$ exposures are known to have changed dramatically just before the study time frame, the use of $\mathrm{PbA}$ exposure data measured over several years is critical to accurate predictions of $\mathrm{PbB}$ concentrations. This study is also notable for showing a surprisingly high value of $\alpha$, even in view of the relatively low $\mathrm{PbA}$ concentrations. Notwithstanding this and some potential problems with the model used by OSHA in the lead standard, our data are in substantial agreement with the OSHA model predictions.

Requests for reprints to: Thomas G Robins, MD, MPH, University of Michigan Occupational Health Program, Department of Environmental and Industrial Health, Ann Arbor, Michigan 48109-2029, USA.

1 United States Department of the Interior, Bureau of Mines, Branch of Nonferrous Metals: Mineral industry surveys. Lead Industry in July 1990. 19 October 1990.

2 United States Department of Labor: Occupational exposure to lead, final standard, 29CFR 1910. 1025. Federal Register 1978;43:54354-509.

3 Ashford NA, Gecht RD, Hattis DB, Katz JI. The effects of OSHA medical removal protection on labor costs of selected lead industries. Massachusetts Institute of Technology, Cambridge: Center for Policy Alternatives, 1977.

4 Hodgkins DG, Hinkamp DL, Robins TG, Levine SP, Schork MA, Krebs WH. Air lead particle sizes in battery manufacturing: potential effects on the OSHA compliance model. Appl Occup Env Hyg 1990;5:518-25.

5 Matte TD, Figueroa JP, Burr GB, Flesch JP, Keenlyside RA, Baker EL. Lead exposure among lead acid battery workers in Jamaica. Am J Ind Med 1989;16:167-77.

6 Williams MK, King E, Walford J. An investigation of lead absorption in an electric accumulator factory with the use of personal samplers. $B r J$ Ind Med 1969;26:202-16.

7 Gartside PS, Buncher CR, Lerner S. Relationship of air lead and blood lead for workers at an automobile battery factory. Int Arch Occup Environ Health 1982;50:1-10.

8 King E, Conchie A, Hiett D, Milligan B. Industrial lead absorption. Ann Occup Hyg 1979;22:213-39.

9 Bishop L, Hill WJ. A Study of the Relationship between blood lead levels and occupational air lead levels. Am Statis 1983;37:471-5.

10 Chavalitnitikul C, Levin L, Chen LC. Study and models of total lead exposures of battery workers. Am Ind Hyg Assoc J 1984;45:802-8.

11 Hryhorczuk DO, Rabinowitz MB, Hessi SM, et al. Elimination kinetics of blood lead in workers with chronic lead intoxication. Am J Ind Med 1985;8:33-41.

12 Schutz A, Skerfving S, Ranstam J, Christoffersson J. Kinetics of lead in blood after the end of occupational exposure. Scand J Work Environ Health 1987;3:221-31.

13 Landrigan PJ. Toxicity of lead at low doses. (review) $\mathrm{Br} J$ Ind Med 1989;46:593-6.

14 Hodgkins DG. The effect of lead-in-air particle size on lead-inblood levels of lead-acid battery workers. Ann Arbor, MI: University of Michigan, 1990. (Doctoral thesis.)

15 Kehoe RA. The Harbon lectures, 1960, The metabolism of lead in man in health and disease. JR Inst Public Health Hyg 1960;24:1-203.

16 Griffin TB, Coulston F, Wills H, Russell JC, Knelson JH. Clinical studies on men continuously exposed to airborne particulate lead. In: Griffin TB, Knelson JH, eds. Lead. Academic Press, London, 1975.

17 Azar A, Snee RD, Habibi K. Relationship of community levels of air lead and indices of lead absorption. In: Environmental health aspects of lead, Proceedings of an International Symposium held in Amsterdam, October 1972. Luxembourg: Comm Eur Communities, 1973.

18 Hammond PB, O'Flaherty EJ, Gartside PS. The impact of airlead on blood-lead in man - a critique of the recent literature. Fd Cosmet Toxicol 1981;19:631-8.

19 Chamberlain AC. Effect of airborne lead on blood lead. Atmos Environ 1983;17:677-92.

20 Rabinowitz MB, Wetherill GW, Kopple JD. Kinetic analysis of lead metabolism in healthy humans. $J$ Clin Invest 1976;58:260-70.

21 Chamberlain AC, Clough WS, Heard MJ. Uptake of lead by inhalation of motor exhaust. Proc $R$ Soc London Ser $B$ 1975;192:77-110. 
22 National Academy of Sciences. Biological effects of atmospheric pollutants: lead, airborne lead in perspective. Washington, DC: National Academy of Sciences, 1972.

23 O'Flaherty EJ, Hammond PB, Lerner SI. Dependence of blood lead half-life on the length of previous lead exposure in humans. Fund Appl Toxicol 1982;2:49-54.

24 Tepper LB, Levin LS. A survey of air and population lead levels in selected American communities. In: Griffin TB, Knelson JH, eds. Lead. London: Academic Press, 1975.
25 Tsuchiya K, Sugita M, Seki Y, Kobayashi Y, Hori M, Park CB. Study of lead concentration in atmosphere and population of Japan. In: Griffin TB, Knelson JH eds. Lead. London: Academic Press, 1975.

26 Johnson DE, Tillery JB, Prevost RJ. Levels of platinum, palladium and lead in populations of southern California. Envir Hlth Perspectives 1975;12:27-33.

Accepted 12 August 1991

\section{Destruction of manuscripts}

From 1 July 1985 articles submitted for publication will not be returned. Authors whose papers are rejected will be advised of the decision and the manuscripts will be kept under security for three months to deal with any inquiries and then destroyed. 